\title{
Morphological analysis of teeth in Bradypus variegatus Schinz, 1825 (Mammalia, Bradypodidae)
}

\author{
Priscilla Virgínio de Albuquerque ${ }^{1 *}$ \\ Felipe Coral dos Santos ${ }^{1}$ \\ André Pukey Oliveira Galvão ${ }^{2}$ \\ Francisco Carlos Amanajás de Aguiar Júnior ${ }^{2}$ \\ Emanuela Paz Rosas ${ }^{3}$ \\ Marcela Barbosa D'Emery ${ }^{3}$ \\ Manuela Figueiroa Lyra de Freitas ${ }^{3}$ \\ ${ }^{1}$ Universidade Federal Rural de Pernambuco, Campus Sede \\ Rua Dom Manoel de Medeiros, s/n, Dois Irmãos, CEP 52171-900, Recife - PE, Brasil \\ ${ }^{2}$ Universidade Federal de Pernambuco, Centro Acadêmico de Vitória de Santo Antão \\ Vitória de Santo Antão - PE, Brasil \\ ${ }^{3}$ Universidade Federal de Pernambuco, Recife - PE, Brasil \\ * Autor para correspondência \\ priscilla2009w@hotmail.com
}

\section{Resumo}

Análise morfológica dos dentes da preguiça Bradypus variegatus Schinz, 1825 (Mammalia, Bradypodidae). Dentre os bichos-preguiça, pode-se destacar a espécie Bradypus variegatus, encontrada especialmente no Nordeste brasileiro. Diante da importância e escassez de informações acerca do sistema digestório de animais silvestres, o objetivo deste artigo é descrever a morfologia dos dentes dessa espécie de preguiça. Para tal, foram utilizados quatro animais adultos, pertencentes ao acervo de anatomia do Centro Acadêmico de Vitória de Santo Antão da Universidade Federal de Pernambuco (UFPE). Os dentes das preguiças foram analisados, retirados das arcadas e, em seguida, submetidos a duas técnicas de preparação histológica de tecido duro, desgaste e descalcificação. As lâminas obtidas foram analisadas em microscópio óptico. As preguiças têm 18 dentes molariformes, com cúspides e espaços interdentais. De acordo com a análise histológica, percebeu-se que os dentes não possuem esmalte, sendo compostos por 1 camada espessa de cemento e 2 camadas de dentina, uma externa e outra interna. A polpa apresenta um aspecto semelhante à humana. Pôde-se constatar, ainda, a presença de ligamento periodontal espesso e vascularizado entre o dente e o osso alveolar, este último com ósteons facilmente identificados.

Palavras-chave: Análise anatômica; Bradypus variegatus; Dente; Descrição histológica

\section{Abstract}

Among the sloth species, we may highlight the Bradypus variegatus, found especially in northeastern Brazil. Given the importance and scarcity of information about the digestive tract of wild animals, this article 
aims to describe dental morphology in this sloth species. To do this, four adult specimens, belonging to the anatomy collection of the Academic Center in Vitória de Santo Antão of the Federal University of Pernambuco (UFPE), were used. The sloth teeth were analyzed, removed from the arch, and they underwent two techniques for hard tissue histological preparation, wear, and decalcification. The blades obtained were analyzed using optical microscopes. Sloths have 18 molariform teeth, with cusps and interdental spaces. According to histological analysis, it was noticed that teeth have no enamel, they consist of 1 thick layer of cementum and 2 layers of dentin, one outside and another inside. The pulp looks like that of human beings. The presence of a thick and vascularized periodontal ligament was also noticed between the tooth and the alveolar bone, the latter with easily identified osteons.

Key words: Anatomical analysis; Bradypus variegatus; Histological description; Tooth

\section{Introduction}

The superorder Xenarthra includes sloths, anteaters, and armadillos. Its great morphological diversity among representatives is worth emphasizing. Sloths belong to the Pilosa order, just as anteaters (GARDNER, 2007). They are distributed into two families according to the number of fingers on the forelimbs: Bradypodidae are three-fingered sloths and the genuses Bradypus, Megalonychidae, and Choloepus consist of two-fingered sloths (GARDNER, 2005).

Brazil is regarded as the largest natural reserve for Bradypodidae (AMORIM, 2000). Bradypus variegatus is the most relevant species, known as the common sloth (SUPERINA; AGUIAR, 2006), showing the largest geographical distribution, it is observed from Honduras to northern Argentina, especially in northeastern Brazil (AMORIM, 2000; CASSANO, 2006).

This is an animal species of arboreal habits, herbivorous, with a high level of food specificity, which resorts to young and mature leaves of some botanical families. Sloths, as other folivore mammals, have a compartmentalized stomach and a relatively short intestine, typical of gastric fermentation, combined with teeth adapted to crush plant material. (CASSANO, 2006). These teeth grow continuously and they are not replaced throughout the animal's life span (CARTELLE, 2000).

As a result of the technological advances of veterinary medicine and the concern about the welfare of wild animals in captivity, it is worth gaining as much knowledge on this species as possible, especially with regard to the structures of the digestive tract that directly interfere with the animal's diet. Considering the sloths' food restriction and the ecological threat they have undergone, Bradypus variegatus Sloth teeth are described both on a macro and a micro basis, thus contributing to knowledge on the dental structure of this species.

\section{Materials and Methods}

\section{Experimental animals}

Four adult Bradypus variegatus sloths, belonging to the anatomy collection of the Academic Center in Vitória de Santo Antão of the Federal University of Pernambuco (UFPE), were used. They have both an authorization from the Brazilian Institute of Environment and Renewable Natural Resources (IBAMA), no 006/2011, and the Ethics Committee on Animal Use (CEUA) of the institution, no 23076.020795/2011-55. All sloths were obtained after natural death and fixed in a $10 \%$ formaldehyde solution, they were kept in a tank using the same solution.

\section{Macroscopic analysis}

Sloths' teeth were analyzed in situ, macroscopically, and the dental formula, as well as teeth shape and classification, was described.

\section{Light microscopy techniques}

Sloths' teeth were removed with hacksaw and scalpel, then they underwent two techniques for hard tissue histological preparation, wear, and 
decalcification. Each animal's teeth were distributed into the techniques. Aiming to prepare and observe the blades, photomicrographs were obtained to analyze the results.

\section{Wear}

Teeth were polished with water sandpaper no. 600 . Equally distributed pressure was exerted on the samples, preventing fracture of the material. Grinding lasted until teeth showed a translucent appearance. After this procedure, the blades were set for examination by optical microscopy.

\section{Decalcification}

Teeth were placed in $15 \mathrm{~mL}$ of formic acid and 10 $\mathrm{mL}$ of sodium citrate; this solution was renewed twice a week for about four months, until teeth acquired a gelatinous consistency. Once decalcification was complete, teeth underwent the histological processing stages, they were immersed in $10 \%$ neutral buffered formalin for a 48 -hour period. After this procedure, teeth were dehydrated in ethanol at increasing concentrations, diaphonized in xylene, impregnated and embedded in paraffin. Blocks were cut on a microtome adjusted to 5 $\mu \mathrm{m}$. The sections obtained were placed on slides smeared with albumin and maintained in an oven at $37^{\circ} \mathrm{C}$ during 24 hour for drying. Sections underwent the staining technique by hematoxylin-eosin (HE) and ready slides were observed under an optical microscope.

\section{Results}

\section{Macroscopic description}

Bradypus variegatus sloths have 18 teeth, 18 in the maxilla and 8 in the jawbone, something which is also seen in other species in the Bradypodidae family (Figure 1).

By analyzing teeth in Bradypus variegatus, all were molariform, and the first pair of maxillary teeth are small-sized when compared to the others. The teeth under analysis have uneven surfaces, showing a marked central depression and faces with cusps. There were spaces between teeth.

\section{Microscopic description}

On histological analysis of the teeth, it was noticed they lack enamel, consisting of 1 thick layer of cementum (Figure 2) and 2 layers of dentin, with an external canaliculi, a large amount of odontoblasts, and few internal dentinal tubules (Figure 3). The outer dentin is probably associated with the repair function, as proposed by Azarias (2005) for Bradypus torquatus, since the lack of enamel culminates in a faster teeth wear. The pulp looks like that of human beings.

FIGURE 1: Photomacrograph of teeth in Bradypus variegatus. (DMX) Maxillary teeth. (DMD) Mandibular teeth.
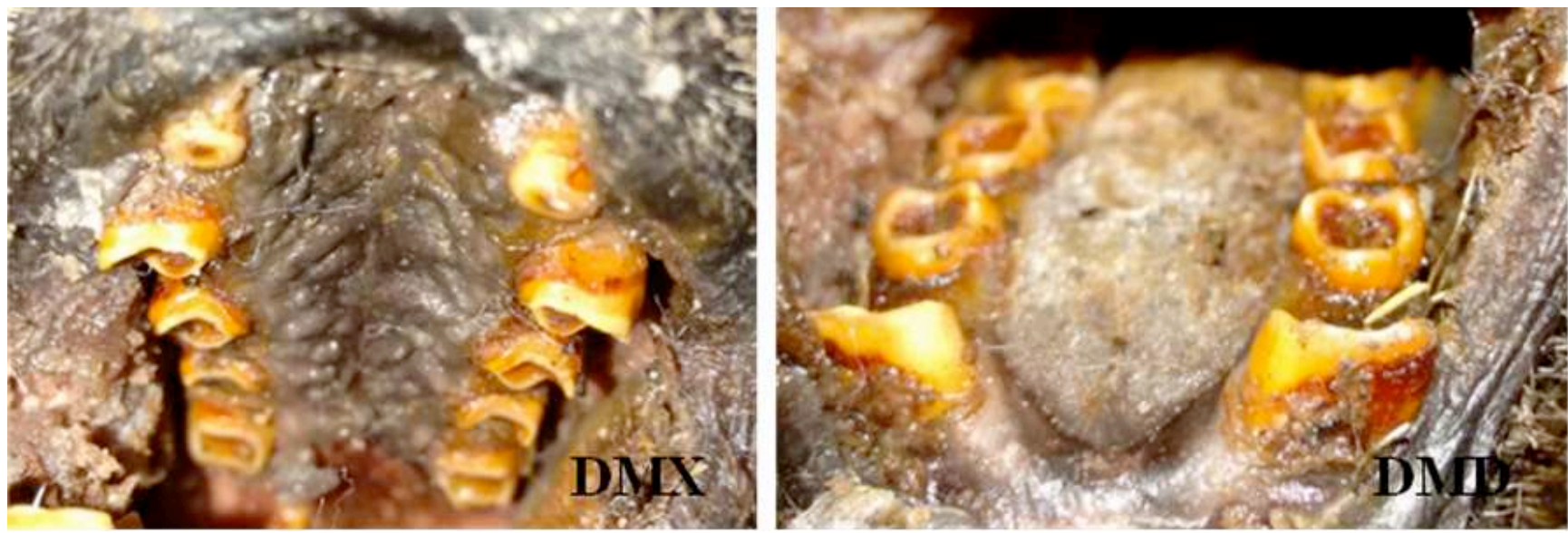
FIGURE 2: Photomicrograph of thick layer of cementum, which wraps teeth dentin in Bradypus variegatus, stained with hematoxylineosin. a) cementum longitudinal section. b) cementum cross-section. Scale pixel corresponds to $0.1 \mathrm{~mm}$ at a $400 \mathrm{x}$ magnification.
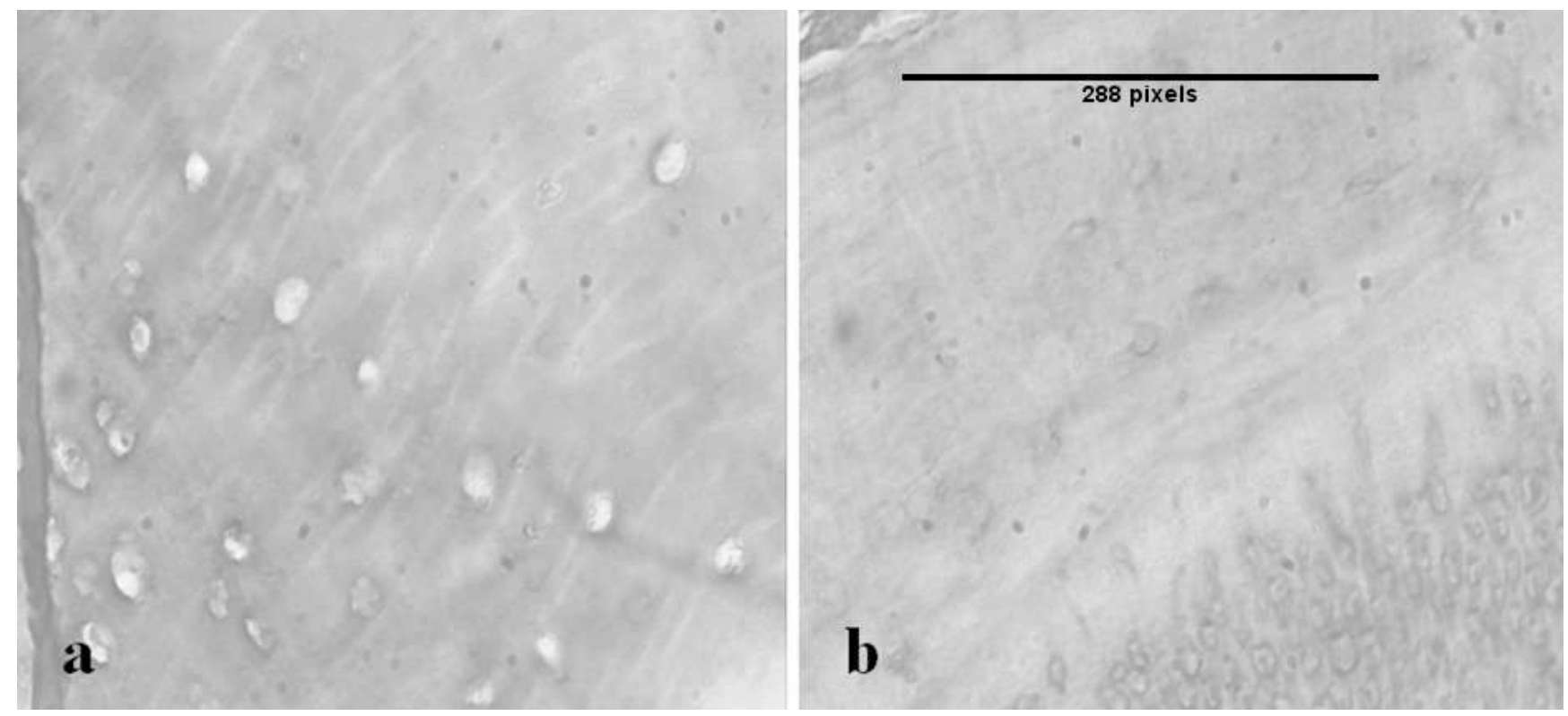

The presence of a thick and vascularized periodontal ligament between the tooth and the bone makes the alveoli visible (Figure 4), this is a mature bone, with osteons, which are not usually observed so close to the tooth.

FIGURE 3: Photomicrograph of the tooth dentin in Bradypus variegatus, external dentin (DE), and inner dentin (DI), obtained through the histological wear technique. Scale pixel corresponds to $0.1 \mathrm{~mm}$ at a 400x magnification.

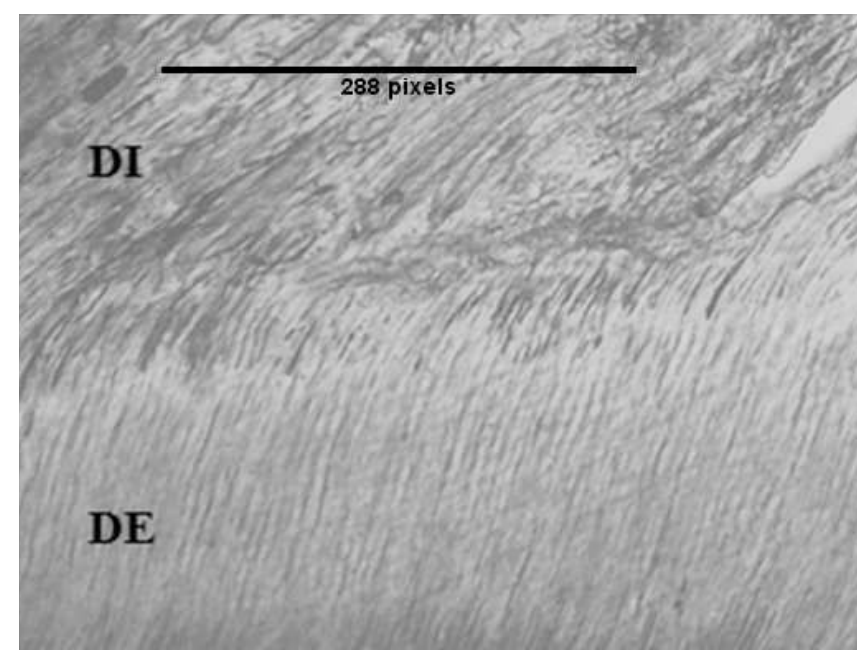

FIGURE 4: Photomicrograph of the tooth in Bradypus variegatus, for observing the periodontal ligament (Li), between the cementum $(\mathrm{C})$ and the alveolar bone $(\mathrm{OA})$, stained with hematoxylin-eosin. Scale pixel corresponds to $0.1 \mathrm{~mm}$ at a $400 \mathrm{x}$ magnification.

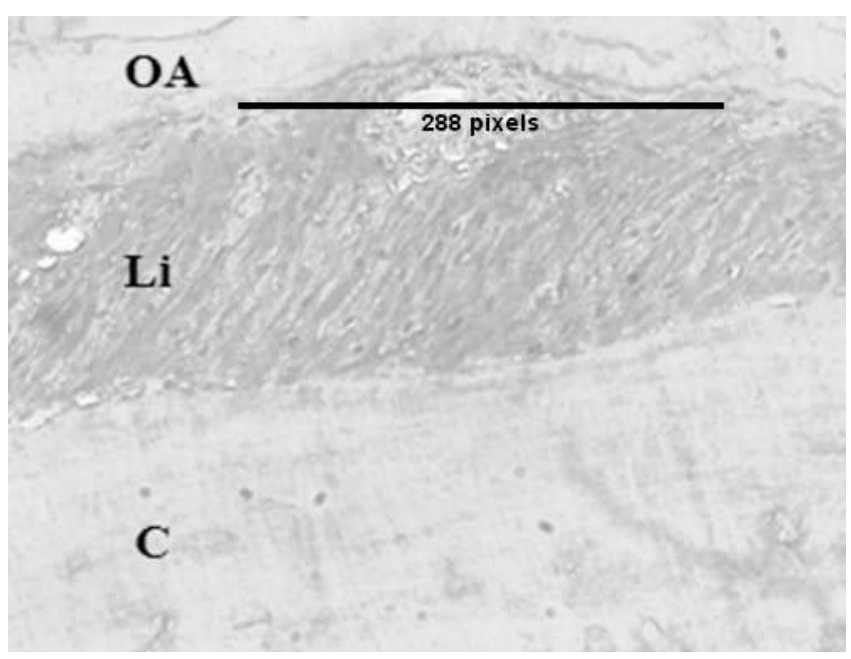

\section{Discussion}

Bradypus variegatus sloths have the tooth formula M 5/4, and a reduced first pair of maxillary teeth, which is used to hold the food, a situation also observed with Bradypus torquatus by Azarias (2005). 
The sloth's molariform teeth resemble those in the armadillo, however, the latter usually has 16 maxillary teeth and 16 mandibular teeth (VENANCIO et al., 2013). Such a tooth shape is associated with these animals' diet, which consists of plant matter, exclusively to sloths along with some invertebrates and vertebrates, in the case of the armadillo (ANACLETO, 2006; CASSANO, 2006). This feature, however, is completely different from that observed in the anteater, which is known by the absence of teeth, a condition justifying the fact that Xenarthras was named as Edentatas (CHINEM, 2010; PINHEIRO et al., 2014).

In general, mammals' teeth consists of the crown that protrudes above the gum and the projected root below it, which binds teeth to the alveoli. Crown and root are overlain by mineralized tissues, i.e. enamel and cementum, respectively. Enamel is regarded as the hardest body tissue, consisting of $96 \%$ of mineral matter, while cementum is similar in composition to bone tissue, although blood vessels and Haversian systems are absent. Both of these covers are on the tooth lap. Within, immediately underneath the enamel and cementum, there is dentin, another mineralized tissue which makes up most of the tooth and surrounds pulp cavity, filled with very innervated and vascularized loose connective tissue, named as tooth pulp. The function of firmly fixing tooth in the socket is related with the periodontal ligament, consisting of connective tissue with thick bundles of collagen fibers inserted into cementum and alveolar bone (JUNQUEIRA; CARNEIRO, 2008).

Interdental spaces were observed in sloths' teeth. However, teeth remain close and they do not rely on the existence of diastema, i.e. a rather considerable space, separating the molar from the others, something which, according to Cartelle (2000), can be observed in sloths.

Upon histological examination of teeth in Bradypus variegatus, it was observed that they lack enamel, and this means higher wear throughout the animal's life span, considering they are herbivores and shred fibrous and tough food. They show selectivity with regard to some plant families, such as the Fabaceae and Moraceae, perhaps an evolutionary strategy to optimize the use of low digestibility and low energy food (CASSANO,
2006). The absence of enamel was also reported in Bradypus torquatus by Azarias (2005).

The existence of two layers of dentin is related to the fact that the external dentin is probably associated with the repair function, as proposed by Azarias (2005) for Bradypus torquatus, since the lack of enamel culminates in faster teeth wear.

The sloths' tooth composition, marked by the absence of enamel and the presence of cementum and two types of dentin, is a feature already analyzed in the extinct giant sloths, from which the current sloths descend, as claimed by Kellner (2012).

According to Cartelle (2008), teeth may be divided into various groups, which have different functions: incisors for cutting, canines for piercing or shattering, and molars for grinding. Based on their types of teeth, animal species may be technically classified into hipsodontes, braquiodontes, and homodontes (AZARIAS, 2005). Hipsodontes have teeth with very long crowns and rather reduced roots. In braquiodontes, teeth are characterized by small differences between the length of the clinical crown and anatomical crown (WIGGS; BLOOM, 2003; PACHALY, 2006; PAIS, 2011), while in homodontes teeth are not specialized, as observed in sloths, whose molariform teeth with no differentiation are associated with their features, such as living in the treetops and eating young leaves or shoots (AZARIAS, 2005). Such habits do not require tough teeth.

In sloths, the presence of cusps may be justified by crown's wear in an exclusively herbivorous diet (AZARIAS, 2005). However, molar teeth with cusps are also analyzed in carnivores, such as the giant otter, and omnivores, like the coati (PIERI et al., 2011; AMORIM et al., 2013). According to Cartelle (2008), in the extinct giant sloths, each tooth came into contact with two opposite teeth and the friction generated meant that the hardest tooth blades wear out the less resistant antagonistic ones, featuring a bite in switchbacks. This condition resembles the sloth under analysis herein. However, the cusps flatten as the animal gets older (AZARIAS, 2005).

Sloths are already born with erupted permanent teeth, a feature also reported by Cartelle (2008), in 
studies with fossil ground sloths. This author claims that the offspring of those extinct mammals were born with conical teeth and already wear at the apex, since they develop chewing within the intrauterine period. Also, just as in all toothed Xenarthras, the current sloth's teeth do not have real roots. Pulpal cavity usually remains open at the base and a tooth grows throughout the animal's life span (CARTELLE, 2000).

Bradypus variegatus slots have 18 molariform teeth with no specialization, out of which 10 are maxillary and 8 are mandibular. The presence of cusps may be noticed, which flatten as the animal gets older. Sloths lack enamel, and teeth consist of pulp, 2 types of dentin, 1 internal and 1 external, cementum-coated. External dentin has a restorative function, before the constant wear of the crown, characterized by lack of enamel. In homodontes teeth, with such a morphological composition, are associated with these animals' habits.

\section{References}

AMORIM, M. J. A. A. L. A placenta da preguiça, Bradypus variegatus - Shinz, 1825. 2000. 78 f. Tese (Doutorado em Anatomia dos Animais Domésticos e Silvestres) - Faculdade de Medicina Veterinária e Zootecnia da Universidade de São Paulo, São Paulo. 2000.

AMORIM, T. B.; MUNDIM, A. T.; FRANZO, V. S.; VULCANI, V. A. S.; GRADELA, A.; NUNES, A. K. R.; ANDRADE, A. C. Aspectos morfológicos e número de dentes da ariranha (Pteronura brasiliensis). In: CONGRESSO BRASILEIRO DE MEDICINA VETERINÁRIA, 40, 2013, Salvador. Resumos... Salvador: CONBRAVET, 2013. Versão eletrônica.

ANACLETO, T. C. S. Distribuição, dieta e efeitos das alterações antrópicas do cerrado sobre tatus. 2006. 139 f. Tese (Doutorado em Ciências Ambientais) - Universidade Federal de Goiás, Goiânia. 2006.

AZARIAS, R. E. G. R. Morfologia dos dentes do bicho-preguiça de coleira (Bradypus torquatus), Illiger, 1811. 2005. $115 \mathrm{f}$. Tese (Doutorado em Anatomia dos Animais Domésticos e Silvestres) Faculdade de Medicina Veterinária e Zootecnia da Universidade de São Paulo, São Paulo. 2005.

CARTELLE, C. Preguiças terrícolas, essas desconhecidas. Ciência Hoje, Rio de Janeiro, v. 27, n. 161, p. 18-25, 2000.
CARTElle, C. O dente. Ciência Hoje, Rio de Janeiro, v. 41, n. 246, p. 28-33, 2008.

CASSANO, C. R. Ecologia e conservação da preguiça-de-coleira (Bradypus torquatus Illiger, 1811) no sul da Bahia. 2006. $127 \mathrm{f}$. Dissertação (Mestrado em Zoologia) - Universidade Estadual de Santa Cruz, Santa Cruz. 2006.

CHINEM, S. Tamanduá-mirim. 2010. São Paulo: Fundação Parque Zoológico de São Paulo. Disponível em: <http://www. zoologico.sp.gov.br/mamiferos/tamanduamirim.htm>. Acesso em: 27 fev. 2016.

GARDNER, A. L. Order Pilosa. In: WILSON, D. E.; REEDER, D. M. (Ed.). Mammals species of the world: a taxonomic and geographic reference. 3. ed. Baltimore: The John Hopkins University Press, 2005. p. 98-102.

GARDNER, A. L. Order Pilosa. In: GARDNER, A. L. (Ed.). Mammals of South America: Marsupials, Xenarthrans, Shrews, and Bats. 1. ed. Chicago and London: The University of Chicago Press, 2007. p. 157-177.

JUNQUEIRA, L. C.; CARNEIRO, J. Histologia básica. Rio de Janeiro: Guanabara Koogan, 2008. 524 p.

KELLNER, A. O dente da preguiça gigante. 2012. Disponível em: <http://cienciahoje.uol.com.br/colunas/cacadores-de-fosseis/ o-dente-da-preguica-gigante>. Acesso em: 27 out. 2015.

PACHALY, J. R. Odontoestomatologia. In: CUBAS, Z. S.; SILVA, J. C. R.; CATÃO-DIAS, J. L. (Ed.). Tratado de animais selvagens - Medicina veterinária. 2. ed. São Paulo: Roca, 2006. p. 1068-1091.

PAIS, F. R. O. Avaliação odontológica em sincrânios de macacoaranha (Ateles sp.). 2011. 141 f. Dissertação (Mestrado em Ciência Animal) - Centro Universitário Vila Velha, Vila Velha. 2011.

PIERI, N. C. G.; MANÇANARES, C. A. F.; BERTASSOLI, B.; LIMA, J. M. N.; THOMAZ, J. M.; CARVALHO, A. F. Classificação morfofuncional dos dentes de quati, Nasua nasua. Pesquisa Veterinária Brasileira, Seropédica, v. 31, n. 5, p. 447-451, 2011.

PINHEIRO, A. C. O.; LIMAA. R.; CARVALHO, A. F.; PEREIRA, L. C.; BRANCO, É. Aspectos morfológicos macro e microscópicos do estômago de tamanduá-mirim (Tamandua tetradactyla). Arquivo Brasileiro de Medicina Veterinária e Zootecnia, Belo Horizonte, v. 66, n. 4, p. 1089-1096, 2014.

SUPERINA, M.; AGUIAR, J. M. A reference list of common names for the edentates. Edentata, Mendoza, v. 7, p. 33-44, 2006.

VENANCIO, A. S.; SANTOS, R. M. C.; LEITE, C. M. C.; MENDES JÚNIOR, A. C.; SILVA, A. B. S.; MOURA, S. M. Classificação anatômica dos dentes do tatu-verdadeiro, Dasypus novemcinctus (Linnaeus, 1758). In: JORNADA ACADÊMICA DE ODONTOLOGIA DA UNIVERSIDADE FEDERAL DO PIAUÍ, 29, 2013, Teresina. Resumos... Teresina: JAO, 2013. Versão eletrônica.

WIGGS, R. B.; BLOOM, B. C. Exotic Placental Carnivore Dentistry. Veterinary Clinics Exotic Animal, College Station, v. 6, n. 3, p. 571-599, 2003. 